$12-21-2021$

\title{
A Dance of Shadows and Fires: Conceptual and Practical Challenges of Intergenerational Healing after Mass Atrocity
}

Brandon Hamber

Ulster University

Ingrid Palmary

University of Johannesburg

Follow this and additional works at: https://digitalcommons.usf.edu/gsp

\section{Recommended Citation}

Hamber, Brandon and Palmary, Ingrid (2021) "A Dance of Shadows and Fires: Conceptual and Practical Challenges of Intergenerational Healing after Mass Atrocity," Genocide Studies and Prevention: An International Journal: Vol. 15: Iss. 3: 100-120.

DOI:

https://doi.org/10.5038/1911-9933.15.3.1779

Available at: https://digitalcommons.usf.edu/gsp/vol15/iss3/12

This Articles is brought to you for free and open access by the Open Access Journals at Digital Commons @ University of South Florida. It has been accepted for inclusion in Genocide Studies and Prevention: An International Journal by an authorized editor of Digital Commons @ University of South Florida. For more information, please contact digitalcommons@usf.edu. 


\title{
A Dance of Shadows and Fires: Conceptual and Practical Challenges of Intergenerational Healing after Mass Atrocity
}

Brandon Hamber

Ulster University

Derry, Northern Ireland

Ingrid Palmary

University of Johannesburg

Johannesburg, South Africa

\begin{abstract}
The red tongues of fire rushed up and flickered from corbel to corbel and from tablet to tablet, and crept along the floor, setting in a blaze the seats and benches. The dance of the shadows passed away, and the dance of the fires began. ${ }^{1}$
\end{abstract}

\section{Introduction}

The question of how societies come to terms with mass atrocity and large-scale political violence, although written about extensively, is still not resolved. This irresolution becomes even more acute when we consider how a past marred by mass atrocity continues to shape the present, not only in the years immediately preceding, but also decades or possibly centuries later. This is evident, for example, in questions of how colonialism and slavery still shape the contemporary world, not to mention the struggles such phenomena present across time for ideas such as collective healing or coming to terms with the past in some way.

This article will address one component of this debate; that is, how we conceptualize the idea of collective healing over time and the consequences thereof for intergenerational healing. In achieving this, we argue that there are two main issues that need to be taken into account because of how important they are for understanding collective healing and because they have been relatively undertheorized in the literature. These are the conditional and ambivalent nature of healing and the importance of connecting the typically disconnected topics of memory, history, and politics in order to understand better how collective healing is rooted in a process of meaning making at an individual and societal level. Developing these two aspects of healing builds a platform from which to discuss the significance of intergenerational notions of healing. This understanding is essential given that questions raised by mass atrocity -including colonialism, slavery, or specific manifestations of racial oppression such as apartheid-continue long after their formal demise.

The article will begin by summarizing some of the authors' work on the issue of how different mechanisms (most specifically transitional justice processes such as truth commissions) may or may not contribute to the notion of healing given that their meaning and significance shift with time and context. Much of the work of the authors of this article has in the past considered the impact of contemporary political conflicts and peace processes, or situations where extensive direct political violence has been committed in the last 10 to 50 years such as in South Africa and Northern Ireland. Specifically, we have considered how processes such as truth commissions, and wider processes of memorialization and symbolic reparations, can contribute to the healing of societies following political violence in and around so-called peace processes. ${ }^{2}$ This work has involved, in addition to academic scholarship, activities such as contributions to establishing memorials or working in collective therapeutic practice with

\footnotetext{
1 William Butler Yeats, Stories of Red Hanrahan, the Secret Rose, and Rosa Alchemica (New York: The MacMillan Company, 1914), 135.

2 Brandon Hamber and Ingrid Palmary, "Gender, Memorialization, and Symbolic Reparations," in The Gender of Reparations: Unsettling Sexual Hierarchies While Redressing Human Rights Violations, ed. Ruth Rubio-Marin (New York: Cambridge University Press, 2009).
}

Brandon Hamber and Ingrid Palmary. "A Dance of Shadows and Fires: Conceptual and Practical Challenges of Intergenerational Healing after Mass Atrocity." Genocide Studies and Prevention 15, no. 3, 100-120. https://doi.org/ 10.5038/1911-9933.15.3.1779.

(C) 2021 Genocide Studies and Prevention. 
victims. We have argued that the impact of contemporary strategies to address mass violence such as truth commissions, memorials, or restorative justice policies are conditional and interrelated in their impact, and also fundamentally linked to developing a new meaning of the past. $^{3}$

Over time we have come to recognize the importance of understanding healing over longer periods of time and, in this article, we focus in on the conceptual areas that we feel have been underdeveloped in the literature yet are essential for better understanding and responding to the healing process intergenerationally. Understanding this builds a platform from which to discuss what such learning and scholarship means intergenerationally.

One of the central challenges in a field of this nature has been the complexity of defining terms given the subjective and contextualized nature of healing. Nevertheless, in describing trauma and healing as intergenerational, we work from the assumption that the second generation refers to those who were born after the official end of war-usually signaled by the signing of peace agreements or political transition-but living with the ongoing legacies of exclusion, conflict, and marginalization that stem from those conflicts. Although this definition is somewhat loose, it recognizes both that the official end to a war is significant for how people experience it, but also that it is inadequate in itself to bring about healing. Similarly, what constitutes trauma for this approach to healing is far broader than a medicalized notion of PTSD even though some studies have indeed shown that PTSD symptomology can exist in the second generation. Rather, it draws on a broad notion of trauma as outlined for example by Eisenbruch who talks of cultural bereavement as a way of capturing the subjective and culturally shaped meaning of the traumatic rather than imagining it can be defined in a diagnostic way that is stable across time and place. ${ }^{4}$ Thus, what constitutes both trauma and healing is shaped by context, which is itself a product of the interplay of history, politics, and memory. It is this interplay that we are concerned with in this article. In working with the assumption that trauma and healing cannot be defined outside of its time and place, we see this article as a contribution to the ongoing conceptualization of this slippery concept.

\section{The Conditional and Ambivalent Nature of Healing}

It is therefore quite significant, a structural element in the realm of human affairs, that men [sic] are unable to forgive what they cannot punish and that they are unable to punish what has turned out to be unforgivable. ${ }^{5}$

Whilst there is a great deal written about processes of collective healing, there are two important components that we draw out here because they have been underdeveloped in the literature; namely, that collective healing is fundamentally linked to developing a new meaning of the past, ${ }^{6}$ and the process is conditional.

Creating a sense of meaning of what happened is a critical part of coming to terms with a legacy of political violence. ${ }^{7}$ This is both an individual and a social task. Mechanisms that seek to uncover what happened in the past by developing a coherent (though not necessarily agreed) set of narratives and processes that create a cognitive meaning of an event or events for victims and wider society is useful when dealing with the impact of violence. ${ }^{8}$ Methods of doing this

\footnotetext{
${ }^{3}$ Ibid.

4 Maurice Eisenbruch, "From Post-Traumatic Stress Disorder to Cultural Bereavement: Diagnosis of Southeast Asian Refugees," Social Science \& Medicine 33, no. 6 (1991), 673-680.

${ }^{5}$ Hannah Arendt, The Human Condition (Chicago: University of Chicago Press, 1998), loc. 3676, Kindle.

6 Ibid.

7 Brandon Hamber, Transforming Societies after Political Violence: Truth, Reconciliation, and Mental Health (New York: Springer, 2009).

${ }^{8}$ Judith Lewis Herman, Trauma and Recovery: The Aftermath of Violence-From Domestic Abuse to Political Terror (London: Pandora, 1992).
} 
are multiple such as truth commissions, trials, social processes such as museums and archives, as well as the sharing of stories about the past in the form of testimony, books, and films.

However, all these processes are conditional and never run in isolation. There is a tendency to evaluate different approaches used to address the past as if they were distinct, unconnected objects (truth commissions, traditional and restorative justice mechanisms, economic equity policies, etc.) and as if individuals engage with these in isolated ways, meaning that we can delineate impact. However, in any society, processes will overlap and unfold over time continually, and are shaped by the challenges of contemporary context, whether this is new wars or social problems from poverty to pandemics.

The word conditional is used because victims of political conflict are unlikely to divorce the questions of truth, justice, responsibility for violations, compensation, and official acknowledgement of what happened to them from their healing process. ${ }^{9}$ Reparations, for example, (including material and nominal measures such as compensation and memorials as well as longer-term interventions to create, for example, inclusive education and economies) are an example of a conditional process. Accepting reparation (or for it to have some reparative psychological impact) is for example interrelated with questions of justice or apology. Without justice, reparations can feel as if they are mere "blood money." 10 Even more challenging concepts such as inter-group forgiveness following political atrocity have been found in a range of contexts to be conditional on other processes such as an apology from the perpetrators, acknowledgement, and accountability. ${ }^{11}$

Take for example the response given by the Japanese so-called "comfort women" to the apology issued by Junichiro Koizumi, Prime Minister of Japan in 2001 in which he "extend[ed] anew my most sincere apologies and remorse to all the women who underwent immeasurable and painful experiences and suffered incurable physical and psychological wounds as comfort women" 12 promising that Japan would "face up squarely to its past history and accurately convey it to future generations." 13 In response, an open letter by the survivors claimed that:

The government of Japan claims it has "apologized many times." But what is the meaning of apology when it fails to reach the heart of those to whom it is made? Apology is not an alibi. The few surviving women do not want token words or charity money. They want an apology that would finally restore their sense of dignity. They also seek compensation with an unequivocal acceptance of the government's state responsibility for its past wrongdoing. ${ }^{14}$

We see clearly in this response the conditionality of healing. The ways that it is shaped by interconnected notions of reparation, apology, acknowledgment, and in this case the restoration of dignity. In short, different approaches will be necessary (e.g., truth recovery processes, apology, acknowledgment) to promote the psychological potential for the healing of

\footnotetext{
${ }_{9}^{9}$ Hamber, Transforming Societies.

10 Brandon Hamber and Richard A. Wilson, "Symbolic Closure Through Memory, Reparation and Revenge in PostConflict Societies," Journal of Human Rights 1, no. 1 (2002), 35-53.

${ }^{11}$ Brandon Hamber, "Forgiveness and Reconciliation: Paradise Lost or Pragmatism?," Peace and Conflict: Journal of Peace Psychology 13, no. 1 (2007), 115-125.

12 Cited in Hamber and Palmary, Gender, Memorialization, and Symbolic Reparations, 372.

$13 \mathrm{Ibid}$. For a more extended discussion on the conditionality of memorialization, and also a discussion of the case, see Hamber and Palmary, Gender, Memorialization, and Symbolic Reparations, 369-374.

14 VAWW-NET Japan, "Responsibility Denied: Japan's Debate Over the Comfort Women," Japan Focus: The Asia-Pacific Journal 5, no. 3 (2007), 1.
} 
victims, but they will seldom be sufficient to deal with all the needs of individuals or even groups of individuals. ${ }^{15}$

In addition, many have also argued and observed that the structural conditions in which individuals live also shape how they might interpret attempts to address a violent past. ${ }^{16}$ For example, living in poverty has been found to shape the views of victims in terms of what is needed to redress the past. ${ }^{17}$ What is focused on in societies emerging from political violence is contested. Truth commissions, for example, have been critiqued for their limited focus on crimes against the "bodily integrity" of individuals 18 and a restricted concentration on civilpolitical rights. ${ }^{19}$ Such an approach ignores socio-economic, systemic, and structural violence, and orientates healing strategies toward the medical and psychological needs of individuals (trauma), rather than considering the impact of the social context on well-being.

It is no wonder that our research, as well as that of others, has routinely shown that victims are ambivalent about the psychological outcomes of their participation in truth commissions and other transitional justice processes. ${ }^{20}$ There is no quick fix or standardized method for addressing the legacy of political violence. Furthermore, how to understand healing (and what needs healing) is wide-ranging and context-specific. Not only are contemporary methods (such as therapy, storytelling, and transitional justice mechanisms) to promote socalled healing conditional and insufficient in themselves to address mass atrocity, but even the notion of healing is problematic in some cases. Arguably using the word healing is anachronistic to the types of mass atrocities (such as slavery or apartheid) and their destruction not only of individuals physically and psychologically, but their wholesale impact on social, cultural, and community life in the present and into the future. Melanie Klein, the psychoanalytic theorist, says once harm is inflicted, we can never completely "make good," 21 and as such, we need to accept that we cannot repair the irreparable (bring back the killed or reconstitute society in the way it was). To this end, the future is always going to be an ambiguous place haunted by the ghosts of the past, while we try to move forward. Coming to terms with the past, especially with relation to mass atrocity, is therefore a life-long and intergenerational process that is dynamic and changes over time.

Healing (mainly at the individual level), therefore, is learning to live with situations of extreme suffering and integrating them into one's life over time so that one can build relationships and engage productively, ensuring that loss does not dominate everyday experiences. ${ }^{22}$ Healing is always a contextual and ambivalent process. This ambivalence is evident in the way that victims of gross violations of human rights must manage their everyday lives (often in changing social circumstances and for many in poverty) and try to live with their loss, while recognizing the irreparable nature of it at the same time as re-imagining the future.

\footnotetext{
${ }^{15}$ Hamber, Transforming Societies.

${ }^{16}$ Lisa J. Laplante, "Transitional Justice and Peace Building: Diagnosing and Addressing the Socioeconomic Roots of Violence through a Human Rights Framework," International Journal of Transitional Justice 2, no. 3 (2008), 331-355; Rama Mani, "Dilemmas of Expanding Transitional Justice, or Forging the Nexus between Transitional Justice and Development," International Journal of Transitional Justice 2, no. 3 (2008), 253-265.

17 Simon Robins, "Towards Victim-Centred Transitional Justice: Understanding the Needs of Families of the Disappeared in Postconflict Nepal," International Journal of Transitional Justice 5, no. 1 (2011), 75-98.

18 Mahmood Mamdani, "Beyond Nuremberg: The Historical Significance of the Post-Apartheid Transition in South Africa,"Politics \& Society 43, no. 1 (2015), 72.

19 Paul Gready and Simon Robins, "From Transitional to Transformative Justice: A New Agenda for Practice," International Journal of Transitional Justice 8, no. 3 (2014), 339-361, accessed December 1, 2021, https://doi.org/ $\underline{10.1093 / \mathrm{ijtj} / \mathrm{iju} 013 .}$.

${ }^{20}$ Hamber and Palmary, Gender, Memorialization, and Symbolic Reparations; Hamber, Transforming Societies; Audrey R. Chapman and Hugo van der Merwe, eds., Truth and Reconciliation in South Africa: Did the TRC Deliver? (Philadelphia: University of Pennsylvania Press, 2007); Catherine C. Byrne, "Benefit or Burden: Victims' Reflections on TRC Participation," Peace and Conflict: Journal of Peace Psychology 10, no. 3 (2004), 237-256.

${ }^{21}$ Melanie Klein, The Psychoanalysis of Children (New York: Grove Press, 1960), 216.

22 Hamber, Transforming Societies.
} 
Victims, and societies in transition, are invariably torn between wanting to let go of the past and focusing on the future and wanting to remember simultaneously. Those who have perpetrated violence (and some are victims as well), as with witnesses and the beneficiaries of political conflicts, are confronted with similar challenges. We need to acknowledge these complex spaces, and in so doing, articulate multi-faceted understandings of the past.

We can, therefore, think of healing as a pendulum in the sense that victims move back and forth between the past, present, and future. "Living with" the suffering of the past will continually change relative to the social and political situation. We can think of the impact of the past as sequential, ${ }^{23}$ i.e., how the traumas of the past are understood relative to different time sequences. Dealing with the impact of political violence can differ for victims during times of conflict, in transition, and during times of peace. The following extract is from a radio show on January 28, 2008, documenting the voices of survivors of the La Mon Hotel bombing by the IRA in 1978 in which 12 people died in Northern Ireland. The comments highlight the victims' unhappiness with Ian Paisley, leader of the Democratic Unionist Party (DUP) and now working in government with Sinn Féin, who were closely linked with the IRA. The survivors are seemingly, or had been, DUP supporters:

(...) for years, we have been told by the Democratic Unionist Party that they wanted investigations carried out (...) to find out who was behind it. Since Paisley and McGuinness got together, we haven't heard one thing about these inquiries... Personally, when I see Paisley and McGuinness [Sinn Féin and Deputy First Minister] together and see them chuckling (...) Aah (...) when people like ourselves sit and watch on the television that sort of thing going on, it would really make you sick. It would make your stomach turn. After all these promises about never sitting down [together] (...) it really is annoying. ${ }^{24}$

What is evident from this excerpt is that for survivors, a transition to peace brings its challenges. Once the conflict is over, individuals can be left questioning the meaning of their suffering and what its significance is in a changed context. For the survivor quoted above, it highlights that moving on for them is different from what moving on means for politicians. They feel distressed that the political party they support is now working with the enemy. At a macro level, the changes the comments refer to are ostensibly positive as the peace agreement in Northern Ireland in 1998, and Ministers Paisley and McGuinness' co-operation was, on the whole, praised for being instrumental to peace. However, at the same time, for some individuals, peace has negatively altered their meaning system. Thus, victimization is not only tied to specific historical incidents, and trauma is not a consistent variable determined by its severity, but is continually reinterpreted across time and constantly revaluated in different contexts. One way, therefore, to think of this is to consider the individual's process of coming to terms with the past as moving at a different pace from what might be happening at a political level. There is often a juxtaposition between what could be considered the individual and collective or political level during peace processes.

Separating victims' needs as if unrelated to the political context is another way of twisting the individual and collective relationship. Hiving off victims' needs as something that can be addressed like a set of symptoms through a series of interventions (e.g., counselling)

\footnotetext{
23 The notion of thinking of trauma as sequential comes from the work of Hans Keilson, who developed the concept of sequential traumatisation. This is discussed at length in David Becker, "Confronting the Truth of the Erinyes: The Illusion of Harmony in the Healing of Trauma," in Telling the Truths: Truth Telling and Peace Building in Post-Conflict Societies, ed. Tristan Anne Borer (Indiana: Notre Dame Press, 2006); Brandon Hamber, Transforming Societies; Hans Keilson, Sequential Traumatization in Children: A Clinical and Statistical Follow-up Study on the Fate of the Jewish War Orphans in the Netherlands, trans. Yvonne Bearne et al. (Jerusalem: The Magnes Press, 1992).

${ }^{24}$ Cited in Hamber, Transforming Societies, 201.
} 
would be an example of this. Perhaps the area where we see the biggest imposition of an external desire to move processes forward at a different pace to that of how individuals might address their needs is in the language of "closure" or when "nations" are expected to be healed, and the society is somehow meant to buy into this rhetoric. An example would be the way that the massacre of Ndebele people during the Gukuruhundi 25 in Zimbabwe has been written off as a "moment of madness" and all memorialization of events were mostly closed down in the name of national unity through the signing of the 1987 Unity Accord between the Zimbabwe African People's Union (ZAPU) and Zimbabwe African National Union (ZANU). ${ }^{26}$ According to Eppel, the meaning of the Unity Accord that brought an end to the Gukuruhundi was primarily interpreted to mean "you cease to exist and we will stop killing you." 27 A similar example is the aftermath of the Rwandan genocide in which the government policy of memorialization and re-education has been criticized for being a form of indoctrination stressing reconciliation over honest dialogue about the past. ${ }^{28}$ This approach in Rwanda, which requires being in step with the state narrative, leads to ostracization of those who refuse to conform to the national storyline, ${ }^{29}$ or certain individual keeping a low profile in society. ${ }^{30}$

Furthermore, nations as entities do not have psyches as such, and merging of individual psychological concepts into the national and political realm ("the nation will be healed") is often more about political projects such as nationalism than representing a precise conceptual category. ${ }^{31}$ Such phenomena, however, are also not only restricted to the level of national discourses. There are many examples of where different groups and governments try and move victim experiences to be in line with their ideas of what they think is needed post-violence. For example, some human rights groups can "pressurize" victims into recasting their experience and suffering into the unfamiliar language of law, rights, and violations. There have also been critiques of international NGOs, for example in Guatemala, focusing on sexual violence (as crucial as this is) in a narrow way undermining a broader focus on the structural conditions that continue to fuel inequality and violence. 32 Similarly, we should not forget that victims themselves are political agents who can and do use their victim status to achieve political ends. For example, they may frame their experiences in a language befitting legal processes or one that makes a claim to economic entitlement.

25 The Gukuruhundi refers to the massacres of the Ndebele people by the notorious 5 Brigade in Matabeleland during the early 1980s. See Catholic Commission for Justice and Peace in Zimbabwe and Legal Resources Foundation, Breaking the Silence, Building True Peace: A Report into The Disturbances in Matabeleland and the Midlands 1980-1988 (Harare: Catholic Commission for Justice and Peace in Zimbabwe and Legal Resources Foundation, 1997); see also Ruth Murambado, “'We Cannot Reconcile Until the Past has been Acknowledged:' Perspectives on Gukurahundi from Matabeleland, Zimbabwe," African Journal on Conflict Resolution 15, no. 1 (2015), 33-58.

${ }^{26}$ Duduzile S. Ndlovu, "Let Me Tell my Own Story: A Qualitative Exploration How and Why 'Victims' Remember Gukurahundi in Johannesburg Today" (PhD diss., University of the Witwatersrand, 2017).

27 Shari Eppel, The Global Political Agreement and the Unity Accord in Zimbabwe (Port Shepstone: Solidarity Peace Trust, 2009), 5, accessed December 1, 2021, http://archive.kubatana.net/docs/opin/eppel gpa vs unity accord 090225.doc.

${ }^{28}$ Chi Mgbako, "Ingando Solidarity Camps: Reconciliation and Political Indoctrination in Post-Genocide Rwanda Note," Harvard Human Rights Journal 18, (2005), 201-223, accessed November 13, 2021, https://ir.lawnet.fordham.edu/ faculty scholarship/377; also see Filip Reyntjens, "Constructing the Truth, Dealing with Dissent, Domesticating the World: Governance in Post-Genocide Rwanda," African Affairs 110, no. 438 (2011), 1-34.

${ }^{29}$ Laura E. R. Blackie and Nicki Hitchcott, "'I am Rwandan:' Unity and Reconciliation in Post-Genocide Rwanda," Genocide Studies and Prevention 12, no. 1 (2018).

30 Grégoire Duruz and Bert Ingelaere, "Silence, Incredulity and Disarray: Youth Experiences of History Education in Contemporary Rwanda," in L'Afrique des Grands Lacs: Annuaire 2013-2014, ed. Filip Reyntjens et al. (Paris: L'Harmattan 2014); Reyntjens, Constructing the Truth.

${ }^{31}$ Hamber and Wilson, Symbolic Closure.

32 M. Brinton Lykes et al., "Political Violence, Impunity, and Emotional Climate in Maya Communities," Journal of Social Issues 63, no. 2 (2007), 369-385; M. Brinton Lykes and Alison Crosby, "Creative Methodologies as a Resource for Mayan Women's Protagonism," in Psychosocial Perspectives on Peacebuilding, ed. Brandon Hamber and Elizabeth Gallagher (Switzerland: Springer, 2015). 
In summary, our work over the last decades has revealed that we can never design a collective process or processes that can fully meet all individual needs because needs are psychologically complex and dynamic. Power is also always at play, not only in who or what violations are focused on which often leads to a contestation about who is most deserving as victims, ${ }^{33}$ but is also tied into the language we use. There are power dynamics and incentives implicit in championing different approaches such as reconciliation, justice, and forgiveness and forgetting. Therefore, we need to think deeply about the context of violence and consider the underlying assumptions and language that are mobilized in the social and political space. To extend the findings we outline above to the notion of collective healing is even more challenging and raises many vexing questions. Applying a temporal and intergenerational lens to these challenges adds further complications and we turn to these questions now as an area in need of ongoing work.

\section{Conditionality and Ambivalence in Intergenerational Healing}

Over time in societies that have experienced mass atrocity, and once those who directly experienced the violence have died, the legacies of mass atrocity seem to live on in the next generation. Subsequent generations give meaning to the atrocities of their parents and grandparents, and even distant relatives and ancestors experienced. One only needs to teach a class on political violence in South Africa or any European country for that matter, as both the authors routinely do, to know that for many students, who have never experienced direct political violence, the colonial past and its reverberations are very much alive. This is embodied in campaigns such as the \#Feesmustfall campaign and its affiliated campaigns such as \#Rhodesmustfall, a campaign in South Africa and later in the UK to remove statues of Cecil John Rhodes, the colonial administrator and financier, from educational institutions as part of broader decolonization of academia. ${ }^{34}$ This student-led movement that swept through South Africa highlights the issues described above; the conditionality of healing on processes of apology, justice and reparation, the interlinkages of different mechanisms of healing and the inevitable ways that shifting contexts change the meaning of processes of healing over time. In a class discussion hosted by one of the authors, a young ANC student representative talked about how there was a need for a new TRC in South Africa. He referred to this as the TRC-C: A Truth and Reconciliation-with Consequences-Commission. The ongoing experiences of poverty, poor education and racial inequality in South Africa have meant, as it did for this young man, that the meaning of the truth commission was reframed as something that "sold-out" black South Africans. This is not an uncommon view in South Africa 20 years after the peace process. ${ }^{35}$ The reconciliatory vision espoused by Nelson Mandela and his legacy is now hotly debated particularly among the youth, many of whom consider Mandela and his cohort of peacemakers as favoring the reconciliation of relationships between black and white South

\footnotetext{
33 Kieran McEvoy and Kirsten McConnachie, "Victimology in Transitional Justice: Victimhood, Innocence and Hierarchy," European Journal of Criminology 9, no 5 (2012), 527-538.

34 Amit Chaudhuri, “The Real Meaning of Rhodes Must Fall," The Guardian, March 16, 2016, accessed December 1, 2021, https:/ / www.theguardian.com/uk-news/2016/mar/16/the-real-meaning-of-rhodes-must-fall; Crispen Chinguno et al., eds., Rioting and Writing: Diaries of Wits Fallists (Johannesburg: Society, Work and Development Institute (SWOP), University of the Witwatersrand, 2017); Brian Kwoba et al., Rhodes Must Fall: The Struggle to Decolonise the Racist Heart of Empire (London: Zed Books, 2018).

35 For a similar example of this changing narrative see Cameron Modisane, "How Mandela's ANC Sold Out the Economic Struggle," News24, April 21, 2014, accessed December 8, 2021, https://www.news24.com/news24/ xArchive/Voices/how-mandelas-anc-sold-out-the-economic-struggle-20180719-2.
} 
Africans over demanding prosecution of apartheid perpetrators and ensuring the redistribution of wealth. ${ }^{36}$

In other words, even in the context of a revered political leader and peacemaker such as Nelson Mandela, the interpretation of the past is never static. As we will argue below, what happens intergenerationally is dependent on what has gone before and the nature of the present, among other factors. This process, as with individual healing, is deeply ambivalent, contingent, and contested. We will argue that the memories and associated traumas of the past are not carbon-copied from one generation to the next. They have a deep symbolic as well as material content. The past, therefore, and how we remember it and come to terms with it, takes on a life of its own, manifesting in a myriad of ways relative to the present in a dynamic process of writing and re-writing that is not merely about the functions memories and the past might serve in the present.

\section{Looking Forward and Looking Back: The Line Between Memory and History}

Most things are forgotten over time. Even the war itself, the life-and-death struggle people went through is now like something from the distant past...But still, no matter how much time passes, no matter what takes place in the interim, there are some things we can never assign to oblivion, memories we can never rub away. They remain with us forever, like a touchstone. ${ }^{37}$

Given the conditional and ambivalent quality of healing, we argue that it is useful to pay attention to the intersection of history, memory, and politics if we are to attend to its intergenerational impacts and create lasting peace. What the above examples already illustrate is how remembering is never an unmediated representation of the past but rather a site of contestation. ${ }^{38}$ Far from being a simple recollection of facts, memory is instead a process of "imagining facts" 39 and an act of interpretation and meaning-making. In this light, memory reflects:

[An] array of different cultural-historical discourses within which this term...is used to describe and carry out certain practices. As a consequence, the topic, and concept of memory must be seen as a cultural-historical phenomenon. ${ }^{40}$

This suggests that memory, while focussed on the past, is shaped and given meaning by the present. ${ }^{41}$ As social and political contexts change, so does the meaning of past violence, and the ways that it is memorialized. Stemming from this, the actions deemed legitimate and

\footnotetext{
${ }^{36}$ See Ashwin Desai and Richard Pithouse, “'But We Were Thousands:' Dispossession, Resistance, Repossession and Repression in Mandela Park," Journal of Asian and African Studies 39, no. 4 (2004), 239-269. But this sentiment is also expressed in the media routinely in South Africa and is an ongoing public debate. See Sunday Independent Editorial, "Anger Behind 'Mandela Sold Us Out' Argument," Sunday Independent, July 31, 2016, accessed May 22, 2020, https://www.iol.co.za/sundayindependent/anger-behind-mandela-sold-us-out-argument-2051482; Takudzwa Hillary Chiwanza, "Did Nelson Mandela Sell Out the Black South Africans?," The African Exponent, August 31, 2017, accessed May 22, 2020, https://www.africanexponent.com/post/8556-some-people-havesuggested-that-mandela-sold-out-south-africa.

${ }^{37}$ Haruki Murakami, Kafka on the Shore, trans. Philip Gabriel (London: Vintage, 2006).

38 Jens Brockmeier, "Introduction: Searching for Cultural Memory," Culture and Psychology 8, no 1 (2002), 5-14; Allan Young, The Harmony of Illusions: Inventing Post-Traumatic Stress Disorder (Princeton: Princeton University Press, 1995).

${ }^{39}$ Mark Freeman, Hindsight: The Promise and Peril of Looking Backward (Oxford: Oxford University Press, 2009).

${ }^{40}$ Brockmeier, Searching for Cultural Memory, 7.

${ }^{41}$ Maurice Bloch, "Internal and External Memory: Different Ways of Being in History," in Tense Past: Cultural Essays in Trauma and Memory, ed. Paul Antze and Michael Lambek (New York: Routledge, 1996), 215-234.
} 
appropriate in response-just as we argued that healing, which concerns events of the past-are also mediated through the present. But much writing in transitional justice and peace studies, and even our own earlier academic work, remains in the immediate post-conflict phase and its resulting processes of remembering, memorialization and attempts at healing. If we take seriously the notion that all history is a history of the present, ${ }^{42}$ we need to understand how the meaning of events change over a longer period, and in fact, are continually changing given the so-called present is never static.

This is particularly important because memory can be functional or instrumental, essentially being interpreted for specific social and political ends, ${ }^{43}$ and always vulnerable to appropriation and manipulation. ${ }^{44}$ Theories of this nature see memory as a "mask concealing the interests of the powerful" that is always given new meaning in new cultural environments. ${ }^{45}$ As Schudson notes: "Examples of instrumentalization are legion. Indeed, the problem may be to find cases of cultural memory that cannot be readily understood as the triumph of present interests over truth." 46 Typically strategies of the instrumentalization of collective memory ${ }^{47}$ include the "glorification of the past, identification with national heroes, use of master narratives, and reducing actors to their assumed motivations and not their actions." 48 This can manifest in so-called "culture wars" or a new "meta-conflict" about history, experience and whose interpretation of the past is correct. This is then used, at different times, to make claims to entitlements, to exclude, to legitimate violence, to recover from violence and / or to promote peace. The collective memories that are articulated (and the resulting silences) shape how society determines who belongs and who does not, and the entitlements associated with belonging. Thus, we need to acknowledge that victims and perpetrators are both used for political gain by others and are themselves political agents.

But there is much more to memory than its instrumental use and misuse. Memory is never the property of an individual. It cannot exist alone but rather stems from our interactions with others. ${ }^{49}$ As Halbwachs reminds us, collective memories of groups are never universal but rather "require[s] the support of a group delimited in space and time." 50 All memory is social, according to Schudson and "located in institutions rather than in individual human minds in the form of rules, laws, standardized procedures, and records, a whole set of cultural practices through which people recognize a debt to the past." ${ }^{51}$ Memory can not only be used by groups to promote political-strategic ends, social solidarity and preserve identity but collective memories can also facilitate change and shape the direction memory takes for future generations. That said, this is a contested process, and although the past can be used and misused in the present, it cannot simply be reconstructed at will. 52

42 Michel Foucault, "Power, Moral Values, and the Intellectual," History of the Present 4, no 1-2 (1988), 11-13.

43 For an applied example see Jocelyn Alexander et al., Violence \& Memory: One Hundred Years in the "Dark Forests" of Matabeleland (Oxford: James Currey, 2000).

44 Pierre Nora, "General Introduction: Between Memory and History," in Realms of Memory: The Construction of the French Past, vol. 1 Conflicts and Divisions, ed. Pierre Nora (New York: Cambridge University Press, 1992), 1-20.

45 Barry Schwartz, “Introduction: The Expanding Past,” Qualitative Sociology 19, no. 3 (1996), 277.

46 Michael Schudson, "Dynamics of Distortion in Collective Memory," in Memory Distortion: How Minds, Brains, and Societies Reconstruct the Past, ed. Daniel L. Schacter (Cambridge: Harvard University Press, 1995$), 351$.

47 The notion of collective memory is a vast academic subject and theoretical underpinnings are beyond the present focus. For the sake of simplicity when we refer to collective memory in this article, we understand collective memory as "the memory of the group while history is the systematic study of the past." See Constance de SaintLaurent et al., "Collective Memory and Social Sciences in the Post-truth Era," Culture E Psychology 23, no. 2 (2017), 153.

48 Ibid., 149.

49 Nora, Between Memory and History.

${ }^{50}$ Maurice Halbwachs, On Collective Memory, trans. Lewis A. Coser (Chicago: University of Chicago Press, 1992 ), 84.

51 Schudson, Dynamics of Distortion, 346.

52 Michael Schudson, Watergate in American Memory: How We Remember, Forget, and Reconstruct the Past (New York: Basic Books, 1992), 207. 
Research looking at the impacts of large-scale memorialization and memory practices (such as truth commissions or the creation of memorials) has tended to focus on the potential for such activities to achieve reconciliation ${ }^{53}$ or how they translate into the everyday lives of people and what sense people make of them. ${ }^{54}$ But much more work is needed to understand how second and third generations respond to and remake the meaning of past atrocities. As Hoffman claims, transmitted memory is an "example of an internalized past, of the way in which atrocity literally reverberates through the minds and lives of subsequent generations," 55 and this reverberation, we argue, is not merely instrumental but social, cultural, political, and psychological.

Here the literature has been unhelpfully dominated by questions of whether those who did not directly experience atrocities are telling the truth and whether/how they too can experience the trauma associated with violence they did not experience. Recent literature has moved away from these overly simplified versions of truth and experience to a recognition that subsequent generations grapple with vivid memories that are handed down through generations and (re)interpret these through the lens of their present in a dynamic way. When we consider mass atrocities such as slavery, to argue this has no traumatic content (used in the widest sense of trauma speaking to a deep psychological wound) for the current generations and descendants of former slaves misses the gravity of such atrocities and how we remember. We need to ask, therefore, what kind of knowledge is possible for later generations? What form does/can this traumatic knowledge take? Is it possible to heal, or at least "live with" such legacies?

Work on the Holocaust perhaps holds the greatest lessons for those of us working in more recent post-conflict societies. This body of literature highlights the tension for later generations between the compulsion to know and the need to forget. ${ }^{6}$ There are many different levels of remembering whereby descendants of the victims of atrocities come to know about them through themes in their lives that become a part of their identity. ${ }^{57}$ In this way, the first generation following mass atrocity shapes the knowledge and forgetting of the second generation, the second generation then shapes this for the next, and so on. This is a dynamic non-linear process as the past is given meaning in light of the present. Recreating and preserving the past therefore becomes about engaging in the discontinuities in history as a "subtle interplay between the inaccessible and the non-existent" while keeping an eye on the present. ${ }^{5}$ That said, despite its fragmented reality, the process of remembering the past also seeks to create a continuity between generations at the same time.59 This continuous and unremitting yet disjointed knowledge of the trauma weaves through the memories of the second generation. After mass atrocity this is a powerful and visceral process. Auerhahn and Laub argue that it is best to conceptualize the second generation after the Holocaust as witnesses even though of course, they did not physically witness the events. ${ }^{60}$ This is what

\footnotetext{
53 Deborah Posel and Graeme Simpson, eds., Commissioning the Past: Understanding South Africa's Truth and Reconciliation Commission (Johannesburg: Witwatersrand University Press, 2002).

54 Hamber and Wilson, Symbolic Closure.

55 Eva Hoffman, After Such Knowledge: Memory, History, and the Legacy of the Holocaust (New York: PublicAffairs Books, 2004), 103.

56 Nanette C. Auerhahn and Dori Laub, "Intergenerational Memory of the Holocaust," in International Handbook of Multigenerational Legacies of Trauma, ed. Yael Danieli (Boston: Springer, 1998).

57 Ibid.

58 Nora, Between Memory and History, 12.

59 Barbara A. Misztal, Theories of Social Remembering (Maidenhead: Open University Press, 2003).

60 Auerhahn and Laub, Intergenerational Memory.
} 
Fine ${ }^{61}$ refers to as absent memory whereby memory is filled with gaps and silences whilst being ever-present:

Subsequent generations of writers who carry the burden of Holocaust history write from a memory vacuum, from the liminal space constituted by the conscious awareness of a history from which one has been materially but not culturally excluded. Such nonwitnesses, as Gary Weissman suggests, might be thought of as being "haunted not by the traumatic impact of the Holocaust, but by its absence." 62

Here the trauma extends not in the re-enactment and refiguring of the event, but in the absence of conscious or unconscious perception of the reality of the experience. ${ }^{63}$ Thus when young people in post-conflict societies "witness" the mass atrocities of the past they do so from the vantage point of the present whilst re-presenting and negotiating a received life experience. The second-generation write memory while also writing into memory; constantly struggling with not having experienced the actual events yet simultaneously experiencing the trauma associated with atrocities.64 Inevitably, this process of creating memory can be used instrumentally in the current context, but what is happening for the subsequent generation as the "witness" the mass atrocities of the past has its own dynamic and powerful resonances at the same time.

Writing on aboriginal experiences, Bombay, Matheson, and Anisman note the effects of intergenerational trauma. ${ }^{65}$ They refer to the second generations trauma as "postmemory" whereby the second generation reclaims memories so powerful that they constitute remembering in their own right. ${ }^{66}$ For Aarons this second generation are "direct heirs to the legacy of traumatic rupture and the indirect recipients of an inheritance existing only in their imperfect imaginations." 67 Brave Heart thus uses the term "historical trauma response" to encapsulate the loss experienced by the second generation. ${ }^{8}$ Such massive traumatic ruptures affect not only individuals but also social dynamics, language, culture and family bonds, and the loss and its impact cannot always be captured in psychological symptoms (even though these may be present).

Thus, Aarons asks what happens when memory is transformed into history, and we would add when it moves through and is embedded in all aspects of cultural and social life. 69 The memories of mass atrocities remain a distressing lens through which the present is interpreted. For example, in post-apartheid South Africa institutions such as education or policing, given their harrowing past under apartheid, can never be free from history to completely recreate it without reference to the past. But importantly for individuals, the

\footnotetext{
61 As cited in Victoria Aarons and Alan L. Berger, Third-Generation Holocaust Representation: Trauma, History, and Memory (Evanston: Northwestern University Press, 2017); see Ellen S. Fine, "Transmission of Memory: The Post-Holocaust Generation," in The Holocaust: Lessons for the Third Generation, ed. Dominick A. Iorio et al. (Lanham: University Press of America, 1997), 185-200.

62 Aarons and Berger, Third-Generation Holocaust Representation, 45.

${ }^{63}$ Dori Laub and Nanette C. Auerhahn, "Knowing and not Knowing Massive Psychic Trauma: Forms of Traumatic Memory," International Journal of Psycho-Analysis 74, no. 2 (1993), 287-302.

64 Aarons and Berger, Third-Generation Holocaust Representation.

65 Amy Bombay, Kim Matheson and Hymie Anisman, “Intergenerational Trauma," Journal de la santé autochtone 5, no. 3 (2009), 6-47, accessed December 1, 2021, https://jps.library.utoronto.ca/index.php/ijih/article/view/ $28987 / 23916$.

66 Bombay et al., Intergenerational Trauma.

67 Aarons and Berger, Third-Generation Holocaust Representation, 62.

68 Maria Yellow Horse Brave Heart and Lemyra De Bruyn, "The American Indian Holocaust: Healing Historical Unresolved Grief," American Indian and Alaska Native Mental Health Research Journal 8, no. 2 (1998), 56-78.

${ }^{69}$ Aarons and Berger, Third-Generation Holocaust Representation.
} 
historical traumatic rupture of mass atrocity not only has an institutional impact. The inheritance of the memories of the past generations of mass atrocity also creates a set of obligations in the next generation-obligations to transmit memory and to continue the struggle (or for the descendants of oppressors to possibly forget the past or attempt re-write it in a more positive light). As Schudson reminds us: "memories are commitments; memories are promises. People will not release important personal or group memories without a struggle."70 This is not a pathological inheritance or some sort of individual imprinting from generation to generation of past traumas in a linear clinical psychological way, but something significantly more complex, i.e., a psychological, socio-cultural, and moral inheritance that plays itself out in relation to the present. Such a process is carried, not solely in individuals, but through social interactions both historical and collective (which in the case of mass atrocity are often pervasive in the society), and only "later" are "internalized in a deeply visceral and unconscious way."71

Memory, for those living after mass atrocity, is thus an inescapable and dynamic morally-loaded weight that the second (and subsequent) generations has to bear, both the descendants of the oppressors and the oppressed. This conceptualization moves beyond a functionalist view of memory, or a narrow form presentism in which the past is "a mere screen on which the contemporary society projects its own image."72 In other words, current memories are not merely there for instrumental political use in the present, but rather the contested nature of mass atrocity (especially in deeply divided societies) creates a complex psychological process of remembering and forgetting playing itself out in an ever-changing present that is rife with competing collective memories and power struggles. This is akin to Schudson's view that instrumentalization never operates independently of other processes and collective memories are always open to contestation. ${ }^{73}$

Just as the immediate victims of mass atrocity might struggle with the desire to recollect traumatic events and forget them at the same time, as we mentioned earlier, subsequent generations from mass atrocity are engaged in a complex psychological process that is beyond stereotypical (often negative) functionalist interpretations. Such functional ways of thinking about memory in South Africa, for example, are evident in such tropes as "playing the race card" assuming bringing up the apartheid past is only for personal benefit, or in the case of white South Africans wanting "reconciliation" is simply as a way of trying to ensure ongoing economic privilege. Put another way, our approach shifts the focus away from both the pathological impact of trauma on subsequent generations, as well as simply assuming bringing up or avoiding the past is merely for personal gain or functional political reasons. Instead, considering the issue of memory in societies living with a legacy of mass atrocity from the perspective of its moral weight and seeing this process as a dynamic psychological liability that is continuously being written and re-written in the present potentially opening a more sensitive space for reflection and dialogue on what intergenerational healing means. This aligns with Pierre Nora's observation that the idea of "generation" only makes sense "in a framework of discontinuity and rupture."74

Of course, one cannot escape the reality of ongoing injustices and the material legacies of colonialism for example. However, the profound fracturing of the social and psychological that mass atrocity creates in subsequent generations, opens the door for the potential for a shared empathic re-imaging, rather than seeing the past as a narrow battleground over who controls the present. When the suffering of the past is of the magnitude of slavery, colonialism or apartheid, arguing for forgetfulness; interpreting memory struggles in the present as merely instrumental; believing that rectifying structural injustices will simply repair history; and

\footnotetext{
70 Schudson, Watergate in American Memory, 207.

71 Pierre Nora, "Generation," in Realms of Memory: The Construction of the French Past, vol. 1 Conflicts and Divisions, ed. Pierre Nora (New York: Cambridge University Press, 1992), 526.

72 Schudson, Dynamics of Distortion, 104.

73 Schudson, Watergate in American Memory.

74 Nora, Generation, 507.
} 
under-estimating the psychological weight mass atrocity places on subsequent generations (who continue to "witness" it) and how this is in constant flux, is a form of historical denialism.

\section{What does this mean for Lasting Peace?}

Excuse me," Belbo said to Agliè, "but your argument is simply post hoc ergo ante hoc. What follows causes what came before. You must not think linearly. The water in these fountains doesn't. Nature doesn't; nature knows nothing of time. Time is an invention

of the West. 75

This discussion brings out five main points that can help us to imagine the conditions for lasting peace. Each of these points reflect back to the importance of understanding the intergenerational impact of mass atrocities.

Firstly, in the fields of transitional justice and peace studies often the horizon of what peace means is too limited in scope and time, embodied in such terms as post-conflict or postagreement. When it comes to mass atrocity and legacy the discussion above shows that the impact lasts much longer, and can destabilize societies well into the future. In post-conflict situations, conflicting groups often have to continue to live with each other and whether violence flares up depends on several complex factors. As Staub notes: "For example, a historical/psychological focus on the military defeat of Serbia by the Turks at Kosovo in 1389 seemed to reaffirm Serb victimization and the sense of the world as dangerous...[and] may have added to the nationalism that resulted in the wars and mass killings in the former Yugoslavia." 76 Thus, as we have discussed, old conflicts shape contemporary experiences in evolving ways.

Secondly, as Staub rightly notes, ${ }^{77}$ reconciliation is a changed attitude and behavior towards the other group and an awareness that a different kind of relationship is possible. However, this changed psychological orientation is rooted in the political, structural, and institutional processes that exist and are set up after peace is negotiated. ${ }^{78}$ In Northern Ireland, for example, the possibility for reconciliation (or at least a peace agreement) was promoted by the increased economic and educational possibilities for the Catholic minority.79 This stands in contrast to the youth of South Africa who makeup $72 \%$ of the unemployed population and have been referred to as a ticking time bomb. These two contrasting examples attest to the significance of the post-conflict context for creating the possibility (or having the potential to undermine) lasting peace and reconciliation. ${ }^{80}$ For subsequent generations the conditions for lasting peace may be more connected to long-term injustices such as cycles of intergenerational poverty that are more difficult to measure than the immediate harm (such as direct human rights violations) that processes such as truth commissions seek to address. Acknowledgement of past atrocities should recognize that the past continues to create structural injustices such as poverty and unequal education, among many others. ${ }^{81}$

\footnotetext{
75 Umberto Eco, Foucault's Pendulum, trans. William Weaver (New York: Harcourt, 1989).

76 Ervin Staub, "Reconciliation after Genocide, Mass Killing, or Intractable Conflict: Understanding the Roots of Violence, Psychological Recovery, and Steps toward a General Theory," Political Psychology 27, no. 6 (2006), 874. 77 Ibid.

78 Ibid.

79 Ibid.

80 Kate Lefko-Everett, Ticking Time Bomb or Demographic Dividend? Youth and Reconcilation in South Africa. SA Reconciliation Barometer Survey (Cape Town: Institute for Justice Reconciliation, 2012). It should be noted, however, scholars have also more recently argued in Northern Ireland that although the two main communities are increasingly reaching economic parity in broad economic terms, a failure to ensure a "peace dividend" postAgreement and improve the quality of people's lives has increased the fragility of the peace process, see Colin Knox, “Northern Ireland: Where is the Peace Dividend?," Policy E Politics 44, no. 3 (2016), 485-503.

81 Pedro Tabensky and Sally Matthews, Being at Home: Race, Institutional Culture and Transformation at South African Higher Education Institutions (Pietermaritzburg: University of KwaZulu-Natal Press, 2015).
} 
In addition to the need for structural and social justice, Staub identifies acknowledgement of the harm caused as an important aspect of long-term peace. ${ }^{82}$ Often perpetrators continue to deny their actions or that they were harmful. In addition, many have shown that deep and meaningful contact across conflicting groups is needed for reconciliation or the rebuilding of relationships. ${ }^{83}$ Forgiveness is facilitated by apology and regret. ${ }^{84}$ But what is interesting here when one considers the second and later generations of mass atrocity is what sort of apology and regret are we talking about, especially if immediate perpetrators are dead? This points to the limits of the individual psychological models of healing used in transitional justice as outlined earlier that specify a conditionality in relation to healing often associated with the actions of the direct perpetrator.

Thirdly, acknowledgement of the past is not merely about addressing the structural through new policies; as necessary as this is. Acknowledgement also contains a symbolic component, i.e., the recognition that injustice of an unimaginable scale took place in the past and it strongly reverberates in the present with real consequences. Acknowledging such realities is not tied to the direct perpetrators, and the enormity of injustices such as slavery, colonialism or apartheid, demands a recognition that moves beyond fixed temporal or geographic realities. The idea of the new generation becomes the symbolic unit of time. ${ }^{85}$

Acknowledgement leads us to the fourth important dimension of lasting peace, which is that institutional and political arrangements need to be set up in a way that is shaped by longterm impacts of atrocities. For example, Vandiginste compares the different approaches take by Rwanda and Burundi after the genocide and refers to the Rwandan approach as a kind of ethnic amnesia where integration and civic identity were expected. ${ }^{86}$ However, he notes that the youth continue to see ethnicity as important and want to know the ethnicity of significant others in their lives. ${ }^{87}$ Thus the meaning of ethnicity is changing, but it remains important even as the national public discourse sees it as taboo. He notes, as an illustration, an ongoing ethnicization of sexual politics among young Rwandans, including the kinds of ethno-gendered stereotypes that commonly used to fuel the genocide. ${ }^{8} \mathrm{He}$ also notes the sense of marginalization of young Hutu men-again a phenomenon that drove the genocide. ${ }^{89}$ On the other hand, the Burundian approach was one of ethnic power-sharing. He argues that both these approaches were driven by the nature of the political transition and the interests of the political elites of the time. ${ }^{90}$ However, they have very different consequences for the second generation and the versions of knowledge/memory that are possible for them. In both these country examples, we see how the representations of the past by the second generation are at odds with those of the first generation because of how they are shaped by context and incomplete processes of healing.

Furthermore, fully acknowledging the legacy such mass atrocities and their ability to continue to shape the present requires an implicit recognition that mass atrocities of such magnitude were not the product of a corrupt regime, a dictator or a handful of perpetrators but societal (or even global) phenomenon. Acknowledging the existence of mass atrocity, and their legacies, therefore further requires that such atrocities are recognized as having a political and social origin (e.g., they originated because of racism, greed, or ideologies of white supremacy).

\footnotetext{
82 Staub, Reconciliation.

83 Thomas F. Pettigrew and Linda R. Tropp, "A Meta-Analytic Test of Intergroup Contact Theory," Journal of Personality and Social Psychology 90, no. 5 (2006), 751-783; Tania Tam et al., “The Impact of Intergroup Emotions on Forgiveness in Northern Ireland," Group Processes \& Intergroup Relations 10, no. 10 (January 1, 2007), 119-136.

${ }^{84}$ Hamber, Forgiveness and Reconciliation.

85 Nora, Generation.

86 Stef Vandeginste, "Governing Ethnicity after Genocide: Ethnic Amnesia in Rwanda Versus Ethnic Power-Sharing in Burundi," Journal of Eastern African Studies 8, no. 2 (2014), 263-277.

${ }^{87}$ Ibid.

${ }^{88} \mathrm{Ibid}$.

89 Ibid.

${ }^{90}$ Ibid.
} 
Without this full acknowledgement, and particularly if we accept our earlier arguments about the weight of intergenerational harm caused by mass atrocity, healing, either collectively or at an individual level, is stymied.

Fifthly and finally, there is a need to understand the complex connections between individual and societal healing. To draw on the work of Dan Bar-Tal, ${ }^{91}$ all conflicts, especially in deeply divided contexts, originate within a specific conflict ethos and are predicated on a set of shared societal beliefs. Built on individual beliefs (basic units of knowledge categories such as ideology, values, norms, decisions, inferences, goals, expectations, religious dogmas, or justifications), societal beliefs are enduring beliefs and collective ideas shared by society members, and perceived by society members as characterizing their society. Not everyone shares all the societal beliefs, and societal beliefs are not merely a collective expression of what different individuals believe, but rather such societal beliefs have transcendent characteristics often embodied in social institutions, debates, and how societies cope. In other words, they tell us about where society comes from and its aspirations about where it is going, and give society meaning in the present. ${ }^{2}$ Societal beliefs are made up of (and also produce) "myths, collective memories, symbols, ideologies, self-images, images of other societies, goals, values, or societal aspirations." 93 Societal beliefs, according to Bar-Tal, then make up the ethos of society, that is, the configuration of central societal beliefs or the unique totality of societal beliefs that provides the central characterization to the society and gives it a particular orientation. An ethos "gives meaning to societal life for society members" and as such is the shared mental basis for society membership. ${ }^{94}$ In other words, shared understandings of society (or groups) are pervasive and also difficult to alter. ${ }^{95}$

The notion of societal beliefs and ethos is helpful when conceptualizing the legacy of mass atrocity as it highlights that changing, and acknowledging the past, requires a shaking of fundamental ideas held by certain groups about the society (or the world) in which such atrocities took place. To this end, it highlights the limits of healing as conceptualized as an individual problem of direct human rights violations. Mass atrocity involves an acknowledgement of the harm done by individual perpetrators alone but the recognition of a more deep-rooted societal ethos that gave rise to the mass atrocity that may not be bound by the present historical reality. Acknowledging the nature of this shadowy ethos can shake the foundations of societal belief systems, and the social identity of particular groups aligned ${ }^{96}$ with perpetrators in some way. It for this reason, when one asks how the legacy of slavery or apartheid should be acknowledged many are left wanting, as a valid acknowledgement would require questioning the fundamental ethos of society (and its founding myths and historical origins) and the heritage of specific groups within those societies.

Bar-Tal sees societal beliefs as allowing individuals to co-operate collectively, and sees them as prone to change (albeit slowly) when a disjuncture between beliefs and function arise:

Societal beliefs change through the process of negotiation, in which leaders, the intellectual elite, media sources, economic decision makers, and other groups take part. The negotiation, which takes the form of public debate, may go on for years, until a new societal belief evolves. ${ }^{97}$

\footnotetext{
${ }^{91}$ Daniel Bar-Tal, Shared Beliefs in a Society: Social Psychological Analysis (Thousand Oaks: Sage, 2000).

92 Ibid.

93 Ibid., 43.

94 Ibid., 140.

${ }^{95}$ Ibid.

96 This alignment can be through familial or even ancestral ties, or the sharing of certain belief systems, linked to a specific group or social identity.

${ }_{97}$ Bar-Tal, Shared Beliefs, 71.
} 
On many levels this is true, and as we can see in societies such as South Africa or Northern Ireland, issues of the past are a daily form of public debate, and it would be difficult not to sustain an argument that societal beliefs have evolved in both societies since peace agreements in the 1990s. However, what we would add to the work of Bar-Tal is much deeper recognition of the symbolic importance of what acknowledgement of past atrocity means and why it is so challenging to attain. In South Africa, for example, truly acknowledging the legacy of apartheid, means acknowledging that the entire colonial project and systemized racism that followed was an indefensible project along with the social ethos that created the system. This brings into question the underlying social meanings, culture, and beliefs held by certain groups, mainly whites who held apartheid societal beliefs and also bequeathed these to their children. Undoing, and faithfully acknowledging the legacy of apartheid for such groups, is akin to a form of existential annihilation.

\section{Conclusion: A Radical Re-Imaging}

Having been brought up in a hair-trigger society where the ground rules were - if no physically violent touch was being laid upon you, and no outright verbal insults were being levelled at you, and no taunting looks in the vicinity either, then nothing was happening, so how could you be under attack by something that wasn't there?98

The challenge for societies emerging from mass atrocity, and arguably with even more longterm legacies of direct and structural violence concerning colonialism, is that we can never "make good." Nevertheless, in public bodies such as truth commissions and prosecution processes, and sometimes in the words of politicians and the general public, closure is often advocated. Immediately following political violence, when concepts such as closure are introduced into public discourse or, for that matter, other tropes ("We need to turn the page but not close the book," "We should forgive but not forget," "We should prioritize the living victims not the dead ones," "We need think about contemporary economic well-being not the past,") we need to be aware that these are intertwined, depending on who is advocating them, with social and political power. In other words, there is often a struggle over who frames the political debate about the past, and who may or not benefit in terms of social and political space in terms of this framing. The past can be used instrumentally in a myriad of ways. But, when considering mass atrocity over a more extended time and intergenerationally what we have added to this in this article is that the recognition of mass atrocity brings with it other demands, an almost immeasurable weight of history and memory on the next generations-a deep psychological rupture and liability. This is present not only for perpetrators and oppressors (or their descendants) but also for those and their families directly, and indirectly, affected by legacies of mass atrocity.

We have chosen to refer to this legacy, not as a form of intergenerational trauma as such, but rather a psychological and moral inheritance that plays itself out in relation to the present but for those involved is akin to witnessing and being part of a profound and ongoing historical rupturing. The challenge when it comes to thinking about healing such ruptures is in the first instance recognizing the full encumbrance of this inheritance on subsequent generation, a weight that can challenge the foundations of the social ethos and the foundation of the societies in which they were born. We cannot dismiss the affective impact of mass atrocity on subsequent generations as functional or instrumental in a one-dimensional way or easily eradicated through structural change or therapeutic interventions alone. The social, cultural, and psychological impact of the past on subsequent generations requires a recognition of harm akin to having experienced it and the creation of social space for this to be shared and re-coded with new meanings relative to the present. Healing and social reconstruction comes not just through what is done but also through the process and the authenticity (often evident in discourse and

98 Anna Burns, Milkman (London: Faber \& Faber, 2018). 
action) with which we try to address social problems. In engaging constructively in the messy business of the past, the overriding task is therefore to create a holding or conducive environment that opens rather than closes social and political space so that different and often divergent voices and approaches to restoration can emerge.

This, however, creates a challenge for processes of conditional forms of meaningmaking typically seen in transitional justice (apology, truth-telling, oral histories, trials), as they tend to conceptualize suffering as largely linked to direct violations within living memory rather than intergenerationally. There is however much to learn from these processes-the unrepairable nature of harm, when reparations and apologies are effective or not, the value and limits of truth-telling and justice-but thinking of large-scale structural, cultural, and social destruction visited upon society through mass atrocities such as colonialism demands a response that moves beyond a liberal institutional approach.

Drawing on what we know about healing in the immediate aftermath of human rights violations for individuals, this process is a deeply ambivalent process. For the second generation of the victims of mass atrocity, as noted, they are often torn between wanting to move on from the past, but also acutely aware of its ever-present nature. For the perpetrators, and their descendants, to fully acknowledge the nature of mass atrocities such as apartheid or slavery, would require the negation of much of the ethos of the essence of the societies from which they come. Arguably this is necessary, albeit challenging to attain, and whether this is forthcoming or not, in most divided societies different groups must continue to live side-byside. To this end, finding ways to represent and acknowledge the gravity of the past is essential. Acknowledgement for almost unimaginable mass atrocity, requires more than one-off events or institutional responses (the grand apology, the truth commission), but rather acknowledgement has to become a lived reality, almost a continuous form of apology (or at least recognition of the past) in many different social interactions (the board room, the sports field, the church, the classroom, in politics) and from different sources (from government, institutions, by associations and individuals) changing in nature, tone, and resonance over time. Symbolic processes also have much to offer. Museums such as the Holocaust Museum in Berlin show some promise in this regard, i.e., by constructing a massive permanent mark on the landscape as a reminder of the magnitude (at least to a modest degree considering the enormity of what happened) of the atrocities committed.

To be sure, social justice, inclusion, and economic equality are also vitally important both structurally and in terms of legislation to address the legacies of the past-but what we have argued here is that there is also a more expansive psychological and cultural process at play when dealing with legacies of mass atrocity. This process is symbolic in so far as we try to capture what the impossible process of acknowledging the real legacy of a system like apartheid, or the ongoing legacies of colonialism in the world today, would entail. We have argued against the idea that how we interpret the past is simply instrumental and aims to serve current strategic or political ends. Of course, this can be the case, but even so, this generally coexists with a much more profound social process of trying to integrate the rupture of mass atrocity into the present. We need to create the social and political space for "each generation to rewrite its generational history" 99 allowing it to move "from first-hand accounts to critical reflection" 100 rather than seeking to dictate how the past should be understood and interpreted or minimizing its generational affect.

Understanding how the legacy of mass atrocity continues to play itself out in the present is therefore not a simple task, but a negotiation that is contingent on many factors from the method of collection and recollection to the wider political process, and these raise questions as to whether it is even appropriate to apply concepts such as healing to collective political processes of remembering - or put another way it means, as we argued earlier, we can only ever think of healing in such contexts as an ambivalent process fraught with

${ }^{99}$ Nora, Generation, 531.

100 Ibid., 530. 
contradictions. If what we have learned about dealing with mass atrocity following peace processes is anything to go by, we can be sure that trying to understand the impact of the past from one generation to the next will not be easily predictable, inevitable, or generalizable. Considering the impact of mass atrocity (and how we remember, live with, and record it) over a longer time horizon, therefore, demands a reframing of some of the now standardized approaches to addressing the past in immediate years after cessation of violence (such as transitional justice). This reframing is as much about political action (addressing inequalities, racism, exclusion, and political debate) as an act of re-imaging given life through constant and contested re-writing.

\section{Bibliography}

Aarons, Victoria and Alan L. Berger. Third-Generation Holocaust Representation: Trauma, History, and Memory. Evanston: Northwestern University Press, 2017.

Alexander, Jocelyn, JoAnn McGregor, and Terence O. Ranger. Violence \& Memory: One Hundred Years in the "Dark Forests" of Matabeleland. Oxford: James Currey, 2000.

Arendt, Hannah. The Human Condition. Chicago: University of Chicago Press, 1998. Kindle.

Auerhahn, Nanette C. and Dori Laub. "Intergenerational Memory of the Holocaust." In International Handbook of Multigenerational Legacies of Trauma, edited by Yael Danieli, 2141. Boston: Springer, 1998.

Bar-Tal, Daniel. Shared Beliefs in a Society: Social Psychological Analysis. Thousand Oaks: Sage, 2000.

Becker, David. "Confronting the Truth of the Erinyes: The Illusion of Harmony in the Healing of Trauma." In Telling the Truths: Truth Telling and Peace Building in Post-Conflict Societies, edited by Tristan Anne Borer, 231-258. Indiana: Notre Dame Press, 2006.

Blackie, Laura E. R. and Nicki Hitchcott. "'I Am Rwandan:' Unity and Reconciliation in PostGenocide Rwanda." Genocide Studies and Prevention: An International Journal 12, no. 1 (2018), 24-37.

Bloch, Maurice. "Internal and External Memory: Different Ways of Being in History." In Tense Past: Cultural Essays in Trauma and Memory, edited by Paul Antze and Michael Lambek, 215-234. New York: Routledge, 1996.

Bombay, Amy, Kim Matheson, and Hymie Anisman. "Intergenerational Trauma." Journal de la santé autochtone 5, no. 3 (2009), 6-47. Accessed December 1, 2021. https:// jps.library.utoronto.ca/index.php/ijih/article/view/28987/23916.

Brave Heart, Maria Yellow Horse and Lemyra De Bruyn. "The American Indian Holocaust: Healing Historical Unresolved Grief." American Indian and Alaska Native Mental Health Research Journal 8, no. 2 (1998), 56-78.

Brockmeier, Jens. "Introduction: Searching for Cultural Memory." Culture and Psychology 8, no. 1 (2002), 5-14.

Burns, Anna. Milkman. London: Faber \& Faber, 2018.

Byrne, Catherine C. "Benefit or Burden: Victims' Reflections on TRC Participation." Peace and Conflict: Journal of Peace Psychology 10, no. 3 (2004), 237-256.

Catholic Commission for Justice and Peace in Zimbabwe and Legal Resources Foundation. Breaking the Silence, Building True Peace: A Report into the Disturbances in Matabeleland and the Midlands 1980-1988. Harare: Catholic Commission for Justice and Peace in Zimbabwe and Legal Resources Foundation, 1997.

Chapman, Audrey R. and Hugo van der Merwe, eds. Truth and Reconciliation in South Africa: Did the TRC Deliver?. Philadelphia: University of Pennsylvania Press, 2007.

Chaudhuri, Amit. "The Real Meaning of Rhodes Must Fall." The Guardian, March 16, 2016. Accessed December 1, 2021. https://www.theguardian.com/uk-news/2016/mar/16/ the-real-meaning-of-rhodes-must-fall.

Chinguno, Crispen, Morwa Kgoroba, Sello Mashibini, Bafana Nicolas Masilela, Boikhutso Maubane, Nhlanhla Moyo, Andile Mthombeni, and Hlengiwe Ndlovu, eds. Rioting and 
Writing: Diaries of Wits Fallists. Johannesburg: Society, Work and Development Institute (SWOP), University of the Witwatersrand, 2017.

Chiwanza, Takudzwa Hillary “Did Nelson Mandela Sell out the Black South Africans?," The African Exponent, August 31, 2017. Accessed May 22, 2020. https:// www.africanexponent.com/post/8556-some-people-have-suggested-that-mandelasold-out-south-africa.

de Saint-Laurent, Constance, Ignacio Brescó de Luna, Sarah H. Awad, and Brady Wagoner. "Collective Memory and Social Sciences in the Post-Truth Era." Culture \& Psychology 23, no. 2 (2017), 147-155.

Desai, Ashwin and Richard Pithouse. "'But We Were Thousands:' Dispossession, Resistance, Repossession and Repression in Mandela Park." Journal of Asian and African Studies 39, no. 4 (2004), 239-269.

Duruz, Grégoire and Bert Ingelaere. "Silence, Incredulity and Disarray: Youth Experiences of History Education in Contemporary Rwanda." In L'Afrique Des Grands Lacs: Annuaire 2013-2014, edited by Filip Reyntjens, Stef Vandeginste, and Marijke Verpoorten, 377397. Paris: L'Harmattan, 2014.

Eco, Umberto. Foucault's Pendulum. Translated by William Weaver. New York: Harcourt, 1989.

Eisenbruch, Maurice. "From Post-Traumatic Stress Disorder to Cultural Bereavement: Diagnosis of Southeast Asian Refugees." Social Science \& Medicine 33, no. 6 (1991), 673-680.

Eppel, Shari. The Global Political Agreement and the Unity Accord in Zimbabwe. Port Shepstone: Solidarity Peace Trust, 2009. Accessed December 1, 2021. http://archive.kubatana.net/ docs/opin/eppel gpa vs unity accord 090225.doc.

Fine, Ellen S. "Transmission of Memory: The Post-Holocaust Generation." In The Holocaust: Lessons for the Third Generation, edited by Dominick A. Iorio, Richard L. Libowitz, and Marcia S. Littell, 185-200. Lanham: University Press of America, 1997.

Foucault, Michel. "Power, Moral Values, and the Intellectual." History of the Present 4, no. 1-2 (1988), 11-13.

Freeman, Mark. Hindsight: The Promise and Peril of Looking Backward. Oxford: Oxford University Press, 2009.

Gready, Paul and Simon Robins. "From Transitional to Transformative Justice: A New Agenda for Practice." International Journal of Transitional Justice 8, no. 3 (2014), 339-361. Accessed December 1, 2021. http:/ / dx.doi.org/10.1093/ijti/iju013.

Halbwachs, Maurice. On Collective Memory. Translated by Lewis A. Coser. Chicago: University of Chicago Press, 1992.

Hamber, Brandon. "Forgiveness and Reconciliation: Paradise Lost or Pragmatism?." Peace and Conflict: Journal of Peace Psychology 13, no 1 (2007), 115-125.

Transforming Societies after Political Violence: Truth, Reconciliation, and Mental Health. New York: Springer, 2009.

Hamber, Brandon and Ingrid Palmary. "Gender, Memorialization, and Symbolic Reparations." In The Gender of Reparations: Unsettling Sexual Hierarchies While Redressing Human Rights Violations, edited by Ruth Rubio-Marin, 324-381. New York: Cambridge University Press, 2009.

Hamber, Brandon and Richard A. Wilson. "Symbolic Closure through Memory, Reparation and Revenge in Post-Conflict Societies." Journal of Human Rights 1, no. 1 (2002), 35-53.

Herman, Judith Lewis. Trauma and Recovery: The Aftermath of Violence-From Domestic Abuse to Political Terror. London: Pandora, 1992.

Hoffman, Eva. After Such Knowledge: Memory, History, and the Legacy of the Holocaust. New York: PublicAffairs Books, 2004.

Keilson, Hans. Sequential Traumatization in Children: A Clinical and Statistical Follow-up Study on the Fate of the Jewish War Orphans in the Netherlands. Translated by Yvonne Bearne, Hilary Coleman, and Deidre Winter. Jerusalem: The Magnes Press, 1992.

Klein, Melanie. The Psychoanalysis of Children. New York: Grove Press, 1960. 
Knox, Colin. "Northern Ireland: Where Is the Peace Dividend?." Policy \& Politics 44, no. 3 (2016), 485-503.

Kwoba, Brian, Roseanne Chantiluke, and Athinangamso Nkopo. Rhodes Must Fall: The Struggle to Decolonise the Racist Heart of Empire. London: Zed Books, 2018.

Laplante, Lisa J. "Transitional Justice and Peace Building: Diagnosing and Addressing the Socioeconomic Roots of Violence through a Human Rights Framework." International Journal of Transitional Justice 2, no. 3 (2008), 331-355.

Laub, Dori and Nanette C. Auerhahn. "Knowing and Not Knowing Massive Psychic Trauma: Forms of Traumatic Memory." International Journal of Psycho-Analysis 74, no. 2 (1993), 287-302.

Lefko-Everett, Kate. Ticking Time Bomb or Demographic Dividend? Youth and Reconcilation in South Africa. SA Reconciliation Barometer Survey. Cape Town: Institute for Justice Reconciliation, 2012.

Lykes, M. Brinton and Alison Crosby. "Creative Methodologies as a Resource for Mayan Women's Protagonism." In Psychosocial Perspectives on Peacebuilding, edited by Brandon Hamber and Elizabeth Gallagher, 147-186. Switzerland: Springer, 2015.

Lykes, M. Brinton, Carlos Martín Beristain, and Maria Luisa Cabrera Pérez-Armiñan. "Political Violence, Impunity, and Emotional Climate in Maya Communities." Journal of Social Issues 63, no. 2 (2007), 369-385.

Mamdani, Mahmood. "Beyond Nuremberg: The Historical Significance of the Post-Apartheid Transition in South Africa." Politics \& Society 43, no. 1 (2015), 61-88.

Mani, Rama. "Dilemmas of Expanding Transitional Justice, or Forging the Nexus between Transitionfal Justice and Development." International Journal of Transitional Justice 2, no. 3 (2008), 253-265.

McEvoy, Kieran and Kirsten McConnachie. "Victimology in Transitional Justice: Victimhood, Innocence and Hierarchy." European Journal of Criminology 9, no. 5 (2012), 527-538.

Mgbako, Chi. "Ingando Solidarity Camps: Reconciliation and Political Indoctrination in PostGenocide Rwanda Note." Harvard Human Rights Journal 18 (2005), 201-223. Accessed November 13, 2021. https:/ ir.lawnet.fordham.edu/faculty scholarship/377.

Misztal, Barbara. Theories of Social Remembering. Maidenhead: Open University Press, 2003.

Modisane, Cameron. "How Mandela's ANC Sold Out the Economic Struggle." News24, April 21, 2014. Accessed December 8, 2021. https://www.news24.com/news24/xArchive/ Voices/how-mandelas-anc-sold-out-the-economic-struggle-20180719-2.

Murakami, Haruki. Kafka on the Shore. Translated by Philip Gabriel. London: Vintage, 2006.

Murambado, Ruth. "'We Cannot Reconcile until the Past Has Been Acknowledged:' Perspectives on Gukurahundi from Matabeleland, Zimbabwe." African Journal on Conflict Resolution 15, no. 1 (2015), 33-58.

Ndlovu, Duduzile S. "Let Me Tell My Own Story: A Qualitative Exploration How and Why 'Victims' Remember Gukurahundi in Johannesburg Today." PhD diss., University of the Witwatersrand, 2017.

Nora, Pierre. "Generation." In Realms of Memory: The Construction of the French Past, vol. 1 Conflicts and Divisions, edited by Pierre Nora, 499-531. Translated by Arthur Goldhammer. New York: Cambridge University Press, 1992.

-----.. "General Introduction: Between Memory and History." In Realms of Memory: The Construction of the French Past, vol. 1 Conflicts and Divisions, edited by Pierre Nora, 1-20. Translated by Arthur Goldhammer. New York: Cambridge University Press, 1992.

Pettigrew, Thomas F. and Linda R. Tropp. "A Meta-Analytic Test of Intergroup Contact Theory." Journal of Personality and Social Psychology 90, no. 5 (2006), 751-783.

Posel, Deborah and Graeme Simpson, eds. Commissioning the Past: Understanding South Africa's Truth and Reconciliation Commission. Johannesburg: Witwatersrand University Press, 2002.

Reyntjens, Filip. "Constructing the Truth, Dealing with Dissent, Domesticating the World: Governance in Post-Genocide Rwanda." African Affairs 110, no. 438 (2011), 1-34. 
Robins, Simon. "Towards Victim-Centred Transitional Justice: Understanding the Needs of Families of the Disappeared in Postconflict Nepal." International Journal of Transitional Justice 5, no. 1 (2011), 75-98.

Schudson, Michael. "Dynamics of Distortion in Collective Memory." In Memory Distortion: How Minds, Brains, and Societies Reconstruct the Past, edited by Daniel L. Schacter, 346-364. Cambridge: Harvard University Press, 1995.

Watergate in American Memory: How We Remember, Forget, and Reconstruct the Past. New York: Basic Books, 1992.

Schwartz, Barry. "Introduction: The Expanding Past." Qualitative Sociology 19, no. 3 (1996), 275282.

Staub, Ervin. "Reconciliation after Genocide, Mass Killing, or Intractable Conflict: Understanding the Roots of Violence, Psychological Recovery, and Steps toward a General Theory." Political Psychology 27, no. 6 (2006), 867-894.

Sunday Independent Editorial. "Anger Behind 'Mandela Sold Us Out' Argument." Sunday Independent, July 31, 2016. Accessed May 22 2020. https://www.iol.co.za/ sundayindependent/ anger-behind-mandela-sold-us-out-argument-2051482.

Tabensky, Pedro and Sally Matthews. Being at Home: Race, Institutional Culture and Transformation at South African Higher Education Institutions. Pietermaritzburg: University of KwaZuluNatal Press, 2015.

Tam, Tania, Miles Hewstone, Ed Cairns, Nicole Tausch, Gregory R. Maio, and Jared B. Kenworthy. "The Impact of Intergroup Emotions on Forgiveness in Northern Ireland." Group Processes \& Intergroup Relations 10, no. 10 (January 1, 2007) 119-136.

Vandeginste, Stef. "Governing Ethnicity after Genocide: Ethnic Amnesia in Rwanda Versus Ethnic Power-Sharing in Burundi." Journal of Eastern African Studies 8, no. 2 (2014), 263277.

VAWW-NET. “Responsibility Denied: Japan's Debate over the Comfort Women." Japan Focus: The Asia-Pacific Journal 5, no. 3 (2007), 1-4.

Yeats, William Butler. Stories of Red Hanrahan, the Secret Rose, and Rosa Alchemica. New York: The MacMillan Company, 1914.

Young, Allan. The Harmony of Illusions: Inventing Post-Traumatic Stress Disorder. Princeton: Princeton University Press, 1995. 